\title{
原著
}
新規治療薬時代以降に診断された多発性骨髄腫患者における 治療モダリティーと予後の変遷

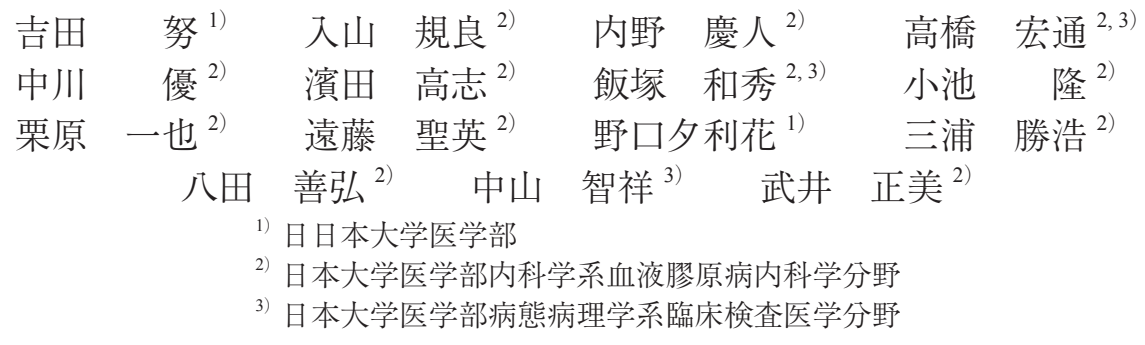

\section{Changes in the Treatment Modality for and Outcome of Patients with Multiple Myeloma after the Introduction of Novel Agents}

\author{
Tsutomu Yoshida ${ }^{1)}$, Noriyoshi IrIYAmA ${ }^{2)}$, Yoshihito UChINO ${ }^{2)}$, Hiromichi TAKahashi ${ }^{2,3)}$, \\ Masaru NAKAgaWA $^{2)}$, Takashi HamadA ${ }^{2)}$, Kazuhide IIzUKA ${ }^{2,3)}$, Takashi KoIKE $^{2)}$, \\ Kazuya Kurihara ${ }^{2)}$, Toshihide Endo ${ }^{2)}$, Yurika Noguchi ${ }^{1)}$, Katsuhiro Miura ${ }^{2)}$, \\ Yoshihiro HATTA ${ }^{2)}$, Tomohiro NAKAYAMA ${ }^{3)}$ and Masami TAKEI ${ }^{2)}$ \\ ${ }^{1)}$ Department of Medicine, Nihon University School of Medicine \\ ${ }^{2)}$ Division of Hematology and Rheumatology, Department of Medicine, Nihon University School of Medicine \\ ${ }^{3)}$ Division of Laboratory Medicine, Department of Pathology and Microbiology, Nihon University School of Medicine
}

This study investigated the outcomes of multiple myeloma (MM) patients after the introduction of bortezomib. We analyzed the backgrounds, treatment statuses, and prognoses of patients who were initially treated between December 2006 and May 2020. Because initial therapy with bortezomib was approved in May 2011 in Japan, the 154 eligible patients were divided into two groups according to whether initial therapy was started before May 2011 (before group, "B" group; $\mathrm{n}=52$ ) or after May 2011 (after group, “A” group; $\mathrm{n}=110$ ). There were no significant differences in the patient backgrounds between the two groups. The 3 -year overall survival rates were $46 \%$ and $75 \%$ in the "B" and "A" groups, respectively, and the survival rate was significantly higher in the latter group. Thalidomide was more frequently used in the "B" group, while bortezomib, pomalidomide, elotuzumab, and daratumumab were more frequently used in the " $\mathrm{A}$ " group. These results suggested that the initial treatment intervention using a novel agent and an appropriate regimen contributed to the improved survival rate of MM patients.

Key words: multiple myeloma, novel agent, prognosis 多発性骨髄腫, 新規治療薬, 予後

要旨 本研究は bortezomib 導入以後の治療の変遷が 多発性骨髄腫 $(\mathrm{MM})$ 患者の予後の改善に寄与している か検討した。2006 年 12 月〜2020 年 3 月に診断された MM 患者を, 2011 年 5 月をカットラインとして層別化 し，患者背景，治療実態および予後を解析した。対象症 例は 154 例で, 2011 年 5 月以前の治療開始（before 群, B 群) が 52 例で以降（after 群，A 群）が 110 例であり， 両群間で患者背景に有意な違いは認めなかった。3 年全 生存率は B 群が 46\%，A 群が $75 \%$ であり A 群が有意に 良好であった。投与された薬荗としては，B 群は thalid- omideの使用が有意に多く, A 群は bortezomib, pomalidomide, elotuzumab, daratumumabの使用が有意に多かっ た。新規治療薬の早期導入と各種レジメンの有効な活用 が患者の生存率改善に寄与していることを示唆する結果 であった。

\section{緒言}

多発性骨髄腫 (multiple myeloma, MM) は，骨髄におけ る形質細胞の単クローン性増殖により特徵づけられ， M 蛋白や様々なケミカルメディエイターを分泌し組織を障 
害する機能的な造血器悪性腫瘍である。高齢者に多くみ られるため, 発症率, 死亡率ともに年々増加傾向にある 疾患である ${ }^{1,2)}$.

近年, $M M$ 患者の予後は新規治療薬の登場により大 幅に改善している ${ }^{3,4)}$. bortezomibについては, 再発抵抗 性患者に対するデキサメタゾン単剤とのランダム化試験 $(\mathrm{APEX} \text { 試験 })^{5)}$ および初発患者に対するメルファラン + プレドニゾロン (MP) 療法と bortezomib を加えたVMP 療法のランダム化試験 (VISTA 試験) ${ }^{6}$ によって MM に 対する有効性が証明されており，本邦でも前向き試験が 実施されている7)。さらに様々な新規治療薬が新たに導 入され，レジメンも多様化し，MM患者の予後はさらに 改善しているものと想定される。ところが, 新規治療薬 導入以降の予後の改善については海外から報告がなされ ているものの ${ }^{8,9)}$, 本邦において新規治療薬時代以降に おける予後の変遷については報告が皆無である.

また，臨床試験においては，それぞれの試験における 適格性基準を満たした患者のみがエントリーされており， 高度な臓器障害を有する患者や全身状態の不良な患者は 除外されている。 MM 患者は初発時に藏器障害や骨病変 などで全身状態が不良な場合も多いため，実診療におい ては，治療の毒性がより高度になると想定される。

したがって本研究では, 新規治療薬時代に治療を開始 された実診療の MM 患者を対象として, 新規治療薬導 入以降の治療実態の変遷および患者予後の改善について 検討した。

\section{患者と方法}

\section{1. 患者}

bortezomib が再発・抵抗性 MM に対して承認された 2006 年 12 月から，2020 年 3 月までに症候性 MM と診 断され, 日本大学医学部附属板橋病院で診療を受けた 患者を対象とした。同施設のデータベースに登録され た多発性骨髄腫患者の診療録を後方視的に解析した。 bortezomib が初発 MM 患者に対して使用可能となった 2011 年 5 月をカットラインとして, 患者を治療開始時 期に基づいて before 群（B 群，2006 年 12 月〜2011 年 5 月治療開始）と after 群（A 群，2011 年 6 月～2020 年 3 月治療開始）として層別化した。 $\mathrm{B}$ 群と A 群の患者背 景および観察期間を群間で比較した上, 全生存 (overall survival, OS) 率について検討した。また群間での各新規 治療薬の使用頻度および自家末梢血幹細胞移植 (autologous peripheral blood stem cell transplantation, aPBSCT) を 実施された患者の割合を比較した。本研究は日本大学医 学部附属板橋病院の臨床研究審査委員会の承認を得て実 施された（承認番号 RK-180710-28，2018 年 6 月承認, 2020 年 6 月更新).

\section{2. 統計学的解析}

群間の比較には Fisher 検定および Mann-Whitney U 検 定を用いた。 OS は死亡をイベントとし，多発性骨髄腫 に対する治療開始日から死亡または最終生存確認日ま でで算出した。これらは Kaplan-Meier 法で算出し, logrank 検定で有意差検定を行った。 B 群とA 群の予後に ついて年齢および International Staging System (ISS) 別に サブセット解析をおこなった。 $p$ 值が 0.05 未満の場合に 統計学的に有意とみなした。解析ソフトは EZR を用い た ${ }^{10)}$.

\section{【結果】}

\section{1. 患者背景}

対象患者は 162 例であり, B 群は 52 例, $\mathrm{A}$ 群は 110 例であった。それぞれの患者内訳を Table 1 に示す。 $\mathrm{B}$ 群とA 群で年齢，性別，腎機能および観察期間にお いて群間に有意差を認めなかったＩSSはそれぞれ 37 例と 99 例で評価可能であり，B 群は stage I が 10 例, stage II が 13 例, stage III が 14 例, 評価不能が 15 例で あった。 A 群は stage I が 34 例, stage II が 25 例, stage III が 40 例， 評価不能が 11 例であり，ISS が評価可能例 においては両群間の病期に有意な違いを認めなかった。

\section{2. 予後}

B 群と A 群の OS を Fig. 1 に示す. 3 年 OS 率は本研 究集団全体で $65 \%$ （95\%信頼区間 [confidence interval, CI] 55-73\%)，B 群が 46\%（95\% CI 31-60\%)，A 群が $75 \%$ （95\% CI 64-83\%）であり，A 群が有意に良好で あった $(p=0.00073)$. 次に本研究集団全体の年齢およ びISS で層別化した予後を Fig. 2 に示す. 65 歳以下とそ れを超える年齢の患者の 3 年 OS 率はそれぞれ 72\%（95 \% CI 56-83\%）と60\%（95\% CI 47-70\%）であり，有 意差は認めなかった $(p=0.368)$ 。一方, ISS 別の 3 年 OS 率は， stage I，II およびIII の群でそれぞれ $81 \%(95$ \% CI 62-91\%), $66 \%$ (95\% CI 44-81\%), $54 \%(95 \%$ CI 38-68\%）であり，予後予測に有用であった（ $p=$ 0.00494)。年齢で層別化した場合の B 群および A 群の 生存率を Fig. 3 に示す。 65 歳以下の患者では, 3 年 OS 率は B 群が 48\%（95\% CI 23-70\%），A 群が 87\%（95\% CI 71-94\%）で A 群が有意に良好であった（ $p=0.0061 ）$. 65 歳を超える患者の 3 年 OS 率はB B 群が $44 \%$ (95\% CI 24-62\%)，A 群が 68\%と (95\% CI 53-80\%)，A 群が有 意に良好であった $(p=0.0225)$. ISS で層別化した場合 の $\mathrm{B}$ 群および A 群の生存率を Fig. 4 に示す. ISS stage I の患者では，3 年 OS 率はB 群が 45\%（95\% CI 14-72 \%)，A 群が96\% (95\% CI 74-99\%）であり A 群が有意 に良好であった $(p=0.00052)$. ISS stage II/III の患者の 3 年 OS 率は B 群が 38\%（95\% CI 18-58\%）, A 群が 69 \% (95\% CI 54-80\%) であり A 群が有意に良好であった 
Table 1 Baseline characteristics of the patients at the time of treatment initiation. Patients who missed data were excluded from statistical analysis.

\begin{tabular}{|c|c|c|c|}
\hline Factors & Before group $(n=52)$ & After group $(n=110)$ & $p$-value \\
\hline Age (years), median (range) & $70(36-83)$ & $68(36-88)$ & 0.955 \\
\hline Sex male, $n$ & 31 & 58 & 0.499 \\
\hline Immunoglobulin subtype, $\mathrm{n}$ & & & \\
\hline $\operatorname{IgG}$ & 33 & 57 & \\
\hline $\operatorname{IgA}$ & 8 & 27 & \\
\hline $\operatorname{IgM}$ & 0 & 1 & \\
\hline $\operatorname{IgD}$ & 1 & 2 & \\
\hline Light chain only & 9 & 21 & \\
\hline Non-secretory & 1 & 2 & \\
\hline eGFR $\left(\mathrm{mL} / \mathrm{min} / 1.73 \mathrm{~m}^{2}\right), \mathrm{n}$ & & & \\
\hline$\geq 40$ & 28 & 74 & 0.564 \\
\hline$<40$ & 16 & 32 & \\
\hline Missing & 8 & 4 & \\
\hline International Staging System, $n$ & & & \\
\hline I & 10 & 34 & 0.509 \\
\hline II & 13 & 25 & \\
\hline III & 14 & 40 & \\
\hline Missing & 15 & 11 & \\
\hline Observation period (months), median (range) & $23(1-130)$ & $24(1-97)$ & 0.9285 \\
\hline
\end{tabular}

(a)

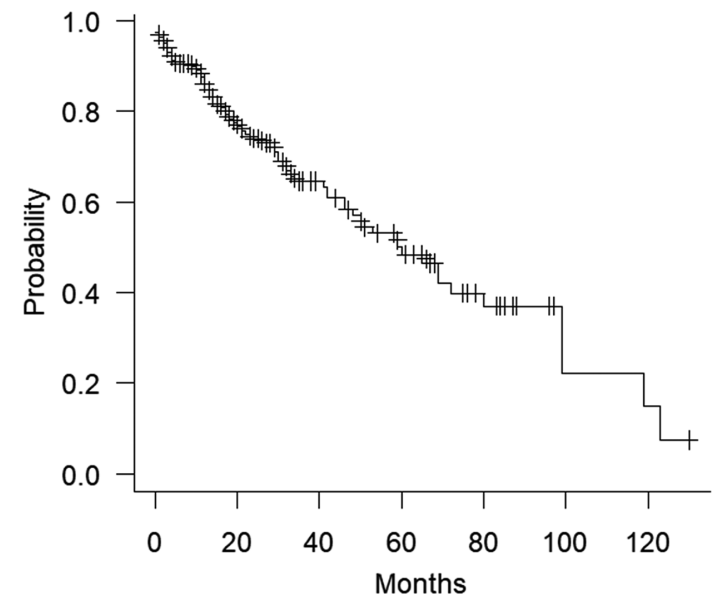

(b)

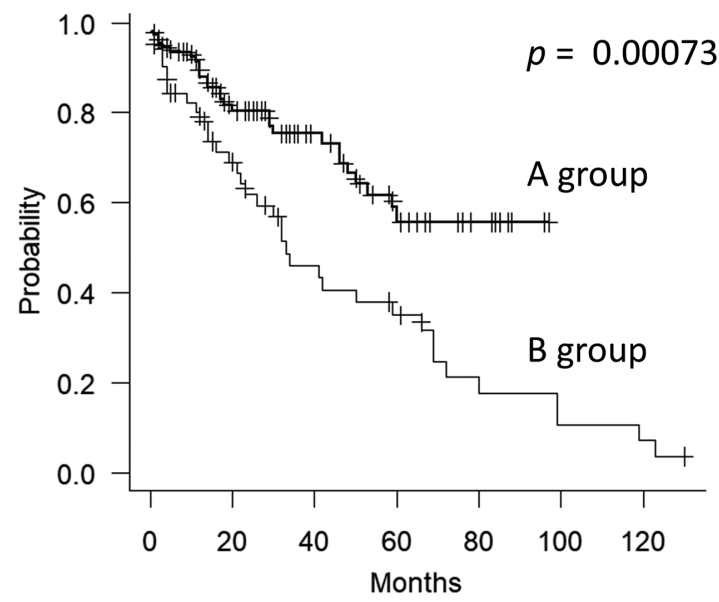

Fig. 1 Kaplan-Meier curves showing the overall survival in the entire cohort (a), and in patients starting treatment before May 2011 ("B" group) and after May 2011 (“A” group) (b)

$(p=0.0187)$

\section{3. 治療実態}

B 群と A 群における治療実態の違いを Fig. 5 に示す. 実際に使用された薬剤の割合としては，B 群は thalidomideの使用が有意に多く, A 群は bortezomib, pomalidomide, elotuzumab, daratumumab の使用が有意に多かっ た。また， $\mathrm{APBSCT}$ の実施は A 群で有意に多かった。さ らに，初期治療としては，B 群はほとんどの症例がアル キル化薬を中心とした，あるいは多剤併用の化学療法を 実施されていたが，A 群は 110 例のうち 98 例（89\%） が bortezomib を含むレジメンで治療を開始されていた。

\section{【考察】}

本研究では, bortezomib が再発・抵抗性症例に対して 利用可能となった 2006 年 12 月以降に治療を開始された 実臨床の MM 患者を対象とし, その後の予後の改善と 治療実態の変化について検討した。我々は本研究におい て, bortezomibの導入以降も患者予後が改善している証 拠を得ることができた (Fig. 1B).

$\mathrm{B}$ 群と A 群は bortezomib が初発で利用可能となった 2011 年 5 月をカットラインとして層別化しており, A 群の患者の大部分が初期治療として bortezomib の投与を 受けている。この点は初回治療で bortezomib を組み込ん 
(a)

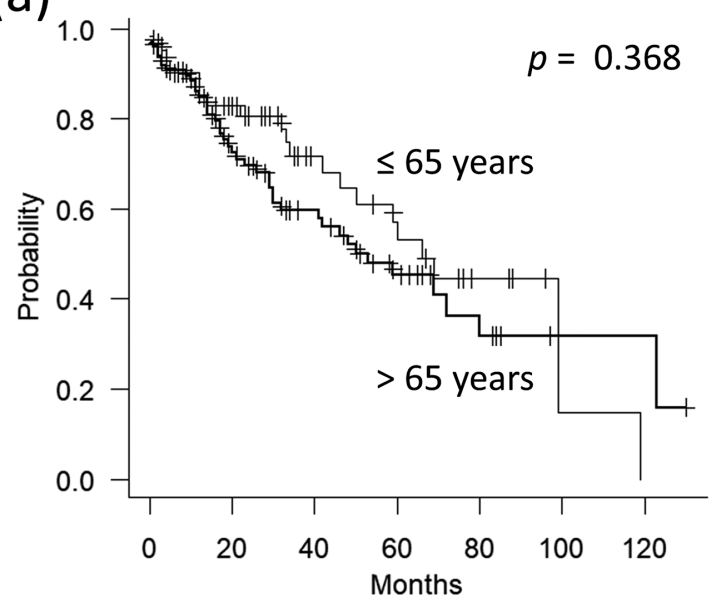

(b)

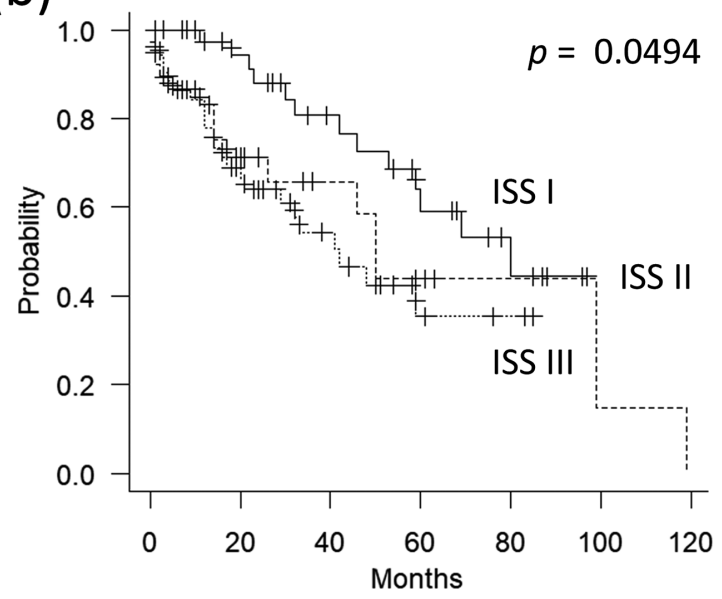

Fig. 2 Kaplan-Meier curves showing the overall survival stratified by patient's age (a) and International Staging System (ISS) (b).

(a)

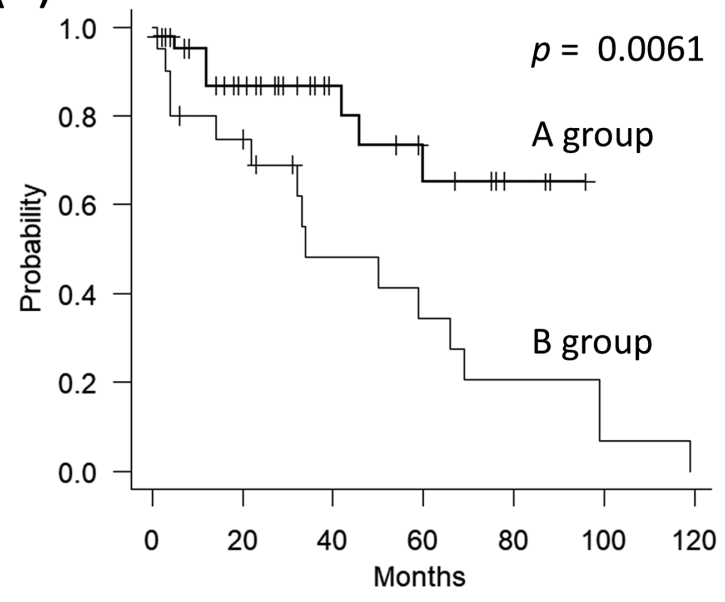

(b)

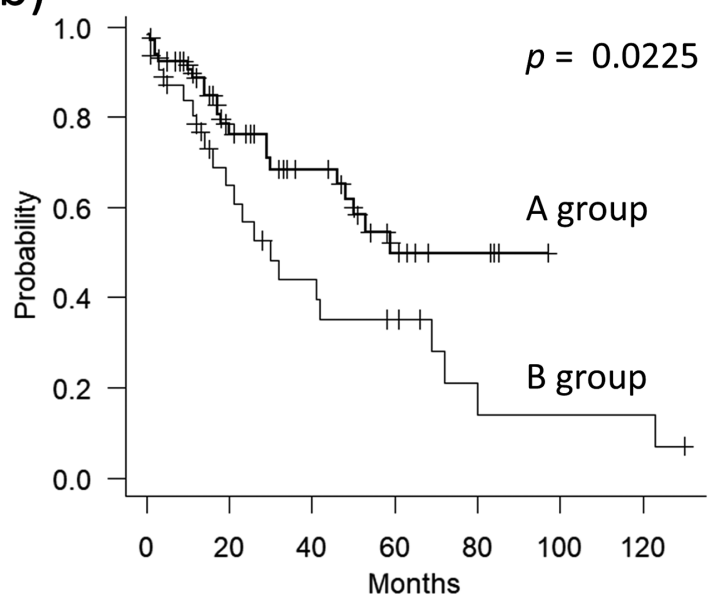

Fig. 3 Kaplan-Meier curves showing the overall survival in the "B" group (therapy started before May 2011) and the "A" group (therapy started after May 2011) among patients aged $\leq 65$ years $(n=64)$ (a) and $>65$ years $(n=98)$ (b).

だレジメンを用いたことで OS が改善するというVISTA 試験の結果に合致する7)。また, bortezomib は重要な有 害事象として末梢神経障害が挙げられ，これは不耐容の 大きな原因であるが, twice weekly 投与から weekly 投与 への変更や皮下注射の承認により毒性の軽減が図られ, 忍容性が改善された点も治療成績の向上に寄与している と推測された ${ }^{11,122}$.

ただし，B 群に比して A 群は再発難治例に対するさ まざまな新規薬剤が利用可能な時代の患者集団であり， bortezomib 不耐容あるいは抵抗性症例に対して利用可 能な治療オプションが異なっていた. Thalidomide と lenalidomide は，それぞれ 2008 年 10 月および 2010 年 6 月に承認された薬剤であるが，その他の新規治療薬はい ずれも本研究のカットライン（2011 年 5 月）以降に承 認となって抢り, 群間でこれらの新規薬剂の使用頻度 は異なっていた (Fig. 5)。ささらに，B 群に比べて A 群は
aPBSCT 実施率が高かったが，この理由としては初期治 療として bortezomib を用いることで疾患のコントロール がより得られやすくなったこと, bortezomibは腎機能を 改善するため, 初発時に高度の腎機能異常のため移植非 適応と考えられたが，治療中に腎機能が回復し aPBSCT が可能となる患者が A 群に見られたこと，それにplerixaforの導入により末梢血幹細胞の採取効率が改善した ことが挙げられる。

したがって，A 群における有意な生存率の改善は，初 期治療としての bortezomib の積極的な使用のみならず, 忍容性を改善する bortezomib 投与方法の開発やさまざ まな新規治療薬の利用可能性，それに支持療法の進歩の 結果であると考えられた。したがって，MM患者の予後 を改善するためには，適切な新規治療薬を積極的に使用 してゆくことが重要であると解釈できる.

また，年齢で層別化した B 群と A 群での OS の比較 
(a)

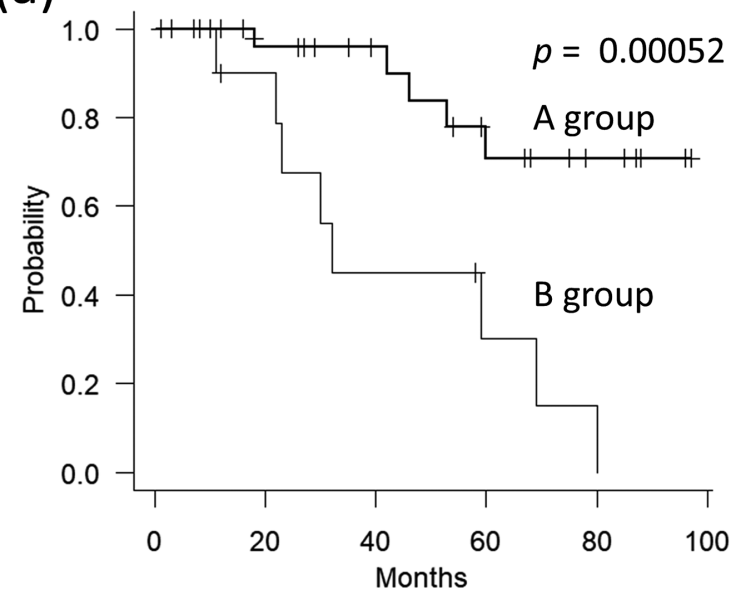

(b)

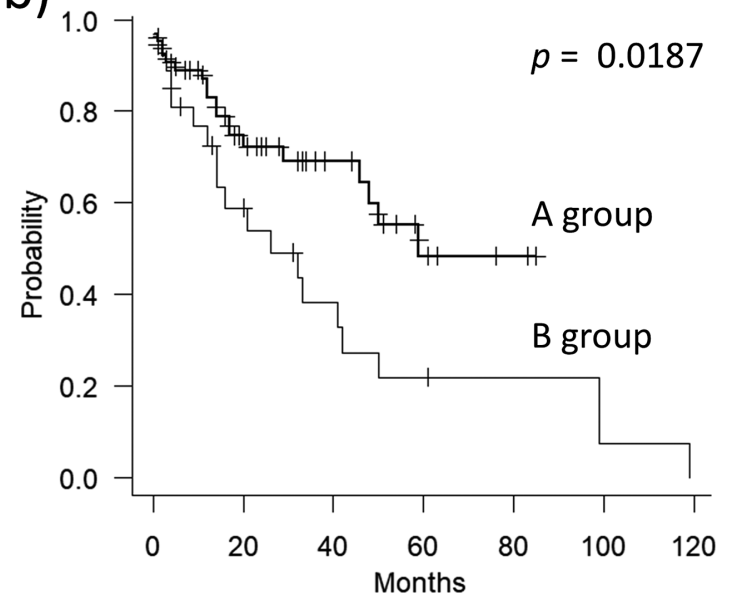

Fig. 4 Kaplan-Meier curves showing the overall survival in the "B" group (therapy started before May 2011) and the "A" group (therapy started after May 2011) among patients diagnosed as stage I (a) and stage II/III (b) by the International Staging System.

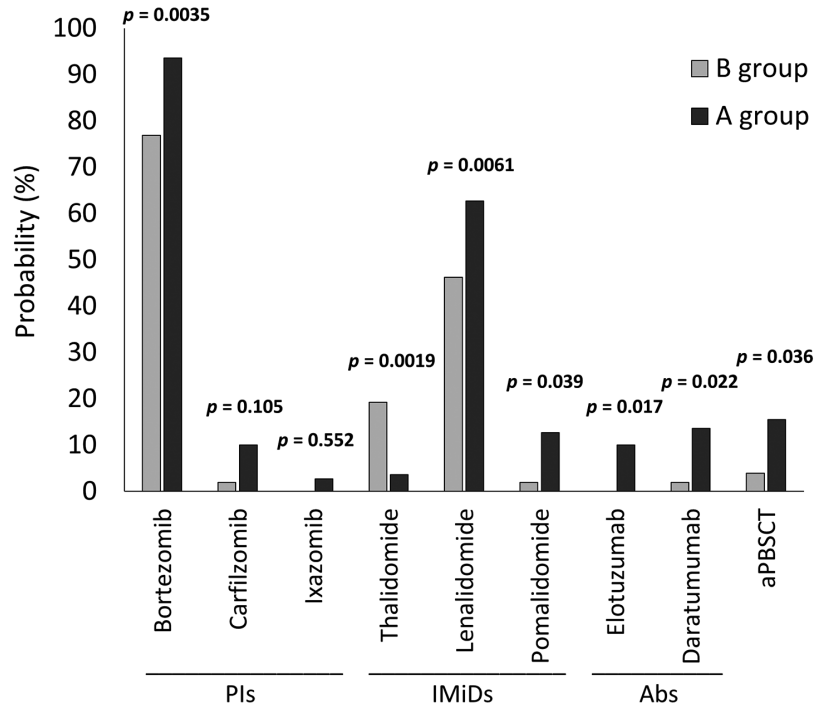

Fig. 5 Treatment modality stratified by the date of starting antimyeloma therapy Patients who started initial treatment between December 2006 and May 2011 are classified into "B" group and those who started after that are classified into "A" group.

PIs: proteasome inhibitors, IMiDs: immunomodulatory drugs, Abs: antibodies, aPBSCT: autologous peripheral blood stem cell transplantation.

においては (Fig. 3), 若年者および高齢者のいずれも A 群が B 群よりも有意に良好な OS を示した。本研究と同 様の観点で時代別の予後を検討した他の研究では，新規 治療薬導入以降, 若年者, 高齢者ともにOS が改善して いるとする報告と ${ }^{9)}$ ，若年者の予後の改善は明らかでな かったとする報告がある ${ }^{8)}$. 後者の Kumar か $^{8)}$ の研究は 本研究と結論が矛盾するが, この研究では初期治療とし て bortezomibの使用頻度が低いこと（18％）が，若年 者の予後を改善していない原因かもしれないと我々は推 測した，実際に，若年者で適応となる
としては, bortezomib を含むレジメンが最も推奨されて いる2)。したがって, bortezomib を初期治療に用いる治 療戦略は, 若年者および高齢者いずれにおいても患者予 後に良好な影響を与えるものと考えられた。

さらに, ISSによる stage 別に OS を検討した結果では (Fig. 4), ISS I, ISS II/III のグループのいずれにおいても B 群に比べて A 群の OS が良好であった. ISS の stage 分類に関わらず， B 群に比べ A 群の OS が有意に良好で あったことは，実臨床の集団において新規治療薬が ISS 不良であっても予後の改善に有効であることを示してい る. 新規治療薬の導入以降, ISS が予後予測に機能する かについては議論があるが ${ }^{13,14)}$, 本研究では新規治療薬 導入以降も ISS は OS の予測因子として機能していた。 しかし一方で，我々は ISS が bortezomib 治療の奏功期間 とは関連しないことを示している ${ }^{15)}$. ISS は $\beta 2$-ミクロ グロブリンと血清アルブミン值の二項目で算出される予 後因子であるため, 疾患自体が持つ特性よりも, 腎機能 などの臓器予備能をより反映していると考えられる。新 規治療薬は腎機能が悪くても使用可能であるものが多い ため, ISSでの stageに関わらず新規治療薬を適正に使 用することで予後の向上が期待できるものと考えられた。

本研究の limitation としては, 単施設で実施する研究 デザインのため, 集積する症例数に限界があったこと, 後方視的研究であるため, ISS の欠損データが存在する こと，それに骨髄腫細胞の染色体異常が明らかでない症 例が多く, Revised ISS ${ }^{16)}$ での評価が困難であったこと が挙げられる。

\section{【結論】}

我々の研究は, 初期治療で bortezomibの使用が可能 になって以来, 実臨床の MM 患者の予後は改善したが, さまざまな新規治療薬を用いたレジメンの積極的な臨床 
応用もまた，予後の改善に寄与していると考えられた。 初発 MM 患者に対しては，患者背景に関わらず，新規 治療薬を含むレジメンの積極的かつ適正な使用が推奨さ れると考えられた。

\section{著者の COI (conflicts of interest) 開示}

入山規良；講演料および謝礼（ブリストルマイヤー ズ・スクイブ, 武田薬品, 小野薬品), 三浦勝浩; 講演料 および謝礼（武田薬品, 小野薬品）, 高橋宏通; 講演料 (ブリストルマイヤーズ・スクイブ), 中川 優 ; 講演料 (ブリストルマイヤーズ・スクイブ), 濱田高志 ; 講演料 (ブリストルマイヤーズ・スクイブ)，八田善弘；講演料 および謝礼（ヤンセンファーマ，ブリストルマイヤーズ・ スクイブ, 武田薬品, 小野薬品), 武井正美; 共同研究 （ブリストルマイヤーズ・スクイブ）

\section{謝 辞}

データ収集に携わった研究技術員，渡辺美遥および馬 詰幸代に深謝する。

\section{文献}

1）がん情報サービス：全国がん罹患モニタリング集計．国 立がん研究センターがん対策情報センター。 (http://gan joho.jp/reg_stat/statistics/brochure/monitoring.html) Accessed 2020 July 25

2）造血器腫瘍診療ガイドライン 2018 年版, III 章骨髄腫. (http://www.jshem.or.jp/gui-hemali/3_1.html\#soron) Accessed 2020 July 25.

3) Ozaki S, Handa H, Saitoh $T$, et al. Trends of survival in patients with multiple myeloma in Japan: A multicenter retrospective collaborative study of the Japanese Society of Myeloma. Blood Cancer Journal 2015; 5: e349.

4) Pulte D, Jansen L, Castro FA, et al. Trends in survival of multiple myeloma patients in Germany and the United States in the first decade of the 21 st century. Br J Haematol 2015; 171: 189-196.

5) Richardson PG, Sonneveld P, Schuster MW, et al. Bortezomib or high-dose dexamethasone for relapsed multiple myeloma.
N Engl J Med 2005; 352: 2487-2498.

6) San Miguel JF, Schlag R, Khuageva NK, et al. Bortezomib plus melphalan and prednisone for initial treatment of multiple myeloma. N Engl J Med 2008; 359: 906-917.

7) Miguel JFS, Schlag R, Khuageva NK, et al. Persistent overall survival benefit and no increased risk of second malignancies with bortezomib-melphalan-prednisone versus melphalanprednisone in patients with previously untreated multiple myeloma. J Clin Oncol 2013; 31: 448-455.

8) Kumar SK, Dispenzieri A, Lacy MQ, et al. Continued improvement in survival in multiple myeloma: Changes in early mortality and outcomes in older patients. Leukemia 2014; 28: $1122-1128$

9) Costa LJ, Brill IK, Omel J, et al. Recent trends in multiple myeloma incidence and survival by age, race, and ethnicity in the United States. Blood Adv 2017; 1: 282-287.

10) Kanda $Y$. Investigation of the freely available easy-to-use software 'EZR' for medical statistics. Bone Marrow Transpl 2013; 48: $452-458$.

11) Bringhen S, Larocca A, Rossi D, et al. Efficacy and safety of once-weekly bortezomib in multiple myeloma patients. Blood 2010; 116: 4745-4753.

12) Moreau P, Pylypenko H, Grosicki S, et al. Subcutaneous versus intravenous administration of bortezomib in patients with relapsed multiple myeloma: A randomised, phase 3, non-inferiority study. Lancet Oncol 2011; 12: 431-440.

13) Maltezas D, Dimopoulos MA, Katodritou I, et al. Re-evaluation of prognostic markers including staging, serum free light chains or their ratio and serum lactate dehydrogenase in multiple myeloma patients receiving novel agents. Hematol Oncol 2013; 31: 356-362.

14) Kuroda J, Shimura Y, Ohta K, et al. Limited value of the international staging system for predicting long-term outcome of transplant-ineligible, newly diagnosed, symptomatic multiple myeloma in the era of novel agents. Int J Hematol 2014; 99: 441-449.

15) Kurihara K, Iriyama N, Miura K, et al. MPC-1 expression in myeloma cells is associated with the efficacy of bortezomib therapy. Med Oncol 2019; 36: 75.

16) Palumbo A, Avet-Loiseau H, Oliva S, et al. Revised International Staging System for Multiple Myeloma: A Report From International Myeloma Working Group. J Clin Oncol 2015; 33: $2863-2869$. 